Vol. 1, No. 2, 2020, pp. 54-64

DOI: https://doi.org/10.2921/07essr57900

Contents lists available at \ournal IICET

Education and Social Sciences Review

ISSN: 2720-8915 (Print) ISSN: 2720-8923 (Electronic)

Journal homepage: https://jurnal.iicet.org/index.php/essr

\title{
Student's performance factor review: engineering science course context
}

\author{
Rosmida Binti Ab Ghani ${ }^{1}$, Najah Binti Mohd Nawi ${ }^{2}$ \\ ${ }^{12}$ Politeknik Sultan Mizan Zainal Abidin, Malaysia
}

\begin{tabular}{l} 
Article Info \\
\hline Article history: \\
Received Apr $9^{\text {th }}, 2020$ \\
Revised May $18^{\text {th }}, 2020$ \\
Accepted Jun $21^{\text {th }}, 2020$ \\
\hline
\end{tabular}

\section{Keyword:}

Performance

Engineering Science

Polytechnic's Students

\begin{abstract}
A mastery in Engineering Science Course is closely related to the physics subjects in schooling which involve problem solving techniques including mathematical skills. Engineering Science Course is considered difficult and complicated that need to be understood since there are many concepts to understand, especially for students who do not take science courses in school. Mastery of a course is closely linked to academic achievement that has a great impact on student achievement. Thus, a study was conducted to identify factors that influence student's performance in the Engineering Science Course at Politeknik Sultan Mizan Zainal Abidin (PSMZA). A total of 179 respondents from four departments; Department of Civil Engineering (JKA), Department of Electrical Engineering (JKE), Department of Mechanical Engineering (JKM) and Department of Mathematical Science \& Computer (JMSK) were involved in this study. The analysis of the study was done using descriptive statistics, T-test and Pearson Correlation using Statistical Package for Social Science (SPSS) version 23. Analysis of the result shows that environment was the main driving force with the mean value of 4.31 being the highest score compared to existing knowledge factors, interests, attitudes, lecturers and peers. T-test analysis also found that there was a significant relationship between attitude and gender differences. Pearson Correlation's analysis found that the relationship between lecturers and interests was average and significant. While peers, environment and interest were strongly related, but significant. It is hoped that the findings of this study will help to provide an overview of the factors that influence student performance in the Engineering Science Course at PSMZA. This will also help JMSK to take preventive measures and improve all aspects of its efforts to improve student performance in the Engineering Science Course at PSMZA.
\end{abstract}

C 2020 The Authors. Published by IICET.

This is an open access article under the CC BY-NC-SA license (https://creativecommons.org/licenses/by-nc-sa/4.0

\section{Corresponding Author:}

Rosmida binti Ab Ghani

Politeknik Sultan Mizan Zainal Abidin

Email: rosmida@psmza.edu.my

\section{Introduction}

The education system is an important foundation for developing a better society and nation (Mior Jamaluddin, M. K. A., 2011). In Malaysia, various educational transformations have been carried out in line with current technological developments and industry needs (Hussin, S. 2014). Various initiatives are being undertaken by our country's education machinery to empower Science, Technology, Engineering and Mathematics (STEM) among students (Abdullah, A. H. et al., 2017) at the school and higher education institutions (HEIs). Public 
higher education institutions (PHEIs) play a significant role in helping to improve the quality of science and technical education in Malaysia through the transformation of higher education that has underlined education and development by increasing the number of researchers, scientists and engineers especially in the development of innovation and research of HEIs ( National Higher Education Strategic Plan-PSPTN, Phase 2, 2011-2015).

Polytechnic is one of the PHEIs with 36 branches throughout Malaysia (Polytechnic Student Admission Division Portal, 2020). Programs of study offered in polytechnics especially in engineering also emphasize science education eligibility through Engineering Science Course. Almost all polytechnic students are required to take Engineering Science Course in semester one. According to Penns State University (2013), Engineering Science is a program discipline that emphasizes understanding and application of engineering and mathematics.

Student achievement in examinations is often linked to the excellence of a student's performance in a particular polytechnic institution. A student's academic excellence is a measure of his or her success and goals. Students have to overcome hustle and bustle of life in campus. Each student does have problems whether related to their studies or personal problems that contribute to the students' failure to take courses especially Engineering Science courses. Students' declining interest in science and mathematics is a worldwide phenomenon (Ayob, 2012).

According to the PSMZA exam achievement record for June 2019 session, the total enrollment in the Engineering Science Course was 960 students and a total of $101(10.52 \%)$ students failed the course. Failure in the course will result in students having difficulty in managing the course registration for the next semester due to the need of repeating the course. This will also force the students to drop the course if the course schedule overlaps with another course. The department also needs to re-offer the course which is seen to increase the number of lecture hours to the lecturers. Therefore, this study was conducted to determine the factors that influence the performance of students taking Engineering Science Course so that preventive measures and best approach by JMSK lecturers and management can be taken to improve students' performance for this course. Therefore, researchers want to conduct research with a primary focus on identifying factors that influence the students' performance of Engineering Science Course from various aspects namely existing knowledge, interests, attitudes, peers, lecturers and the environment.

\section{Objectives of the Study}

i. Identify factors that influence student performance in mastering Engineering Science Course.

ii. Identify the differences between students' attitude and gender in mastering Engineering Science Course.

iii. Identify the relationship between lecturers, peers, and the environment with student's interest.

\section{Study Questions}

i. What factors influence students' performance in Engineering Science Courses?

ii. Is there a difference between students' attitude and gender in mastering Engineering Science Course?

iii. Is there any relationship between lecturers, peers, and the environment with student's interest?

\section{Hypothesis}

i. $\mathrm{H}_{0-1}$ : There is no difference between student's attitude and gender.

ii. $\mathrm{H}_{1-1}$ : There is a difference between student's attitude and gender.

i. $\mathrm{H}_{0-2}$ : There is no relationship between lecturers, peers and the environment and the student's interest.

ii. $\mathrm{H}_{1-2}$ : There is a relationship between the faculty, peers and the environment in the interest of students

\section{Importance of Study}

The results of this study are expected to provide input and assist the management of JMSK in planning more effective measures to ensure that the performance of the Engineering Science Course is enhanced and improved in line with customer needs and requirements.

\section{Scope of the Study}

This study was conducted to identify the factors that influence the performance of the Engineering Science Course students at PSMZA. The sample of this study includes diploma and pre-diploma students in semester one. 


\section{Method}

\section{Study Design}

This writing methodology is focused on quantitative style research applications that are based on survey method. The use of this survey technique by implementing questionnaire in this research is based on rationality (Mohd Majid, K. 2000).

\section{Population and Sampling}

The respondents of the study were PSMZA first semester students who took Engineering Science Course involving JKA, JKE, JKM and JMSK students. This study used simple random sampling. The selection is based on the students taking the Engineering Science Course for December 2019 session.

The total number of first semester students taking the December 2019 Engineering Science Course was 212. According to Krejcie and Morgan, (1970), the minimum sample size needed to represent the population was 140 people such as the Krejcie Morgan Table.

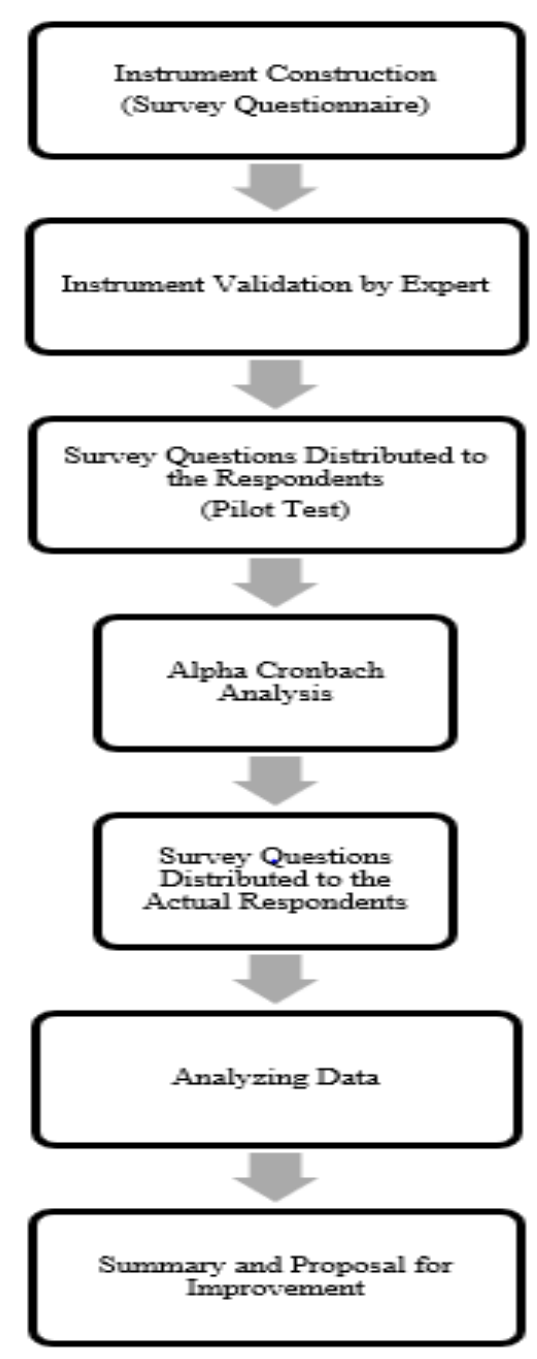

Figure 3.1

Researchers began the study by developing an instrument called a questionnaire to find out factors that influence students' performance in the Engineering Science Course. It is important to identify what is the main factor influencing the students' performance.

Therefore, the researchers divided the questionnaire instrument into two main sub-sections, Part A: Demographics and Part B: which included existing knowledge, interests, attitudes, lecturers, peers and a total of 35 items constructed for both. section. The instrument construction uses five likert scales such as Table 3.1 below. 
Table 1. Interpretation of Likert Scale Value for Study Instruments

$\begin{array}{cc}\text { Scale } & \text { Value } \\ 5 & \text { Strongly Agree } \\ 4 & \text { Agree } \\ 3 & \text { Slightly Disagree } \\ 2 & \text { Disagree } \\ 1 & \text { Strongly Disagree }\end{array}$

According to Gay and Air Asian (2003), expert review and endorsement are essential to ensure that the research instrument meets the needs of the researcher based on the research objectives set after the completion of the instrument development, Bunimin (2016) asserts that individual selection as a panel of experts is depending on the objective built into the research question. A review of this instrument should be performed to ensure that the items being constructed are adequate and balanced. Instrument validity involves face validity, content validity and construct validity.

Based on expert research, Section A contains 5 items and Section B contains 30 items divided into subsections namely existing knowledge, interests, attitudes, lecturers, peers and the environment. There are items that the sentence structure improves so that it can be read more clearly so that it can be understood and answered easily by the respondents.

After obtaining expert consent, the study instrument consisting of two aspects: Part A (5 items), and Part B (30 items).

Table 2. Constructing Questionnaire Items

\begin{tabular}{ccc}
\hline Construct Item & Number of Original Items & Number of Items \\
\hline Demographic & 5 & 5 \\
Existing Knowledge & 5 & 5 \\
Interest & 5 & 5 \\
Attitude & 5 & 5 \\
Lecturer & 5 & 5 \\
Peers & 5 & 5 \\
Environment & 5 & 5 \\
Total Number of Items & 35 & 35 \\
\hline
\end{tabular}

The study instrument was distributed to 30 respondents for the pilot study after receiving expert approval. According to Krejcie and Morgan (1970) and Sekaran (2006), for a sample of 217 people, 30 were sufficient to verify the reliability of the constructed items. Table 3 above shows the value of the reliability coefficient as a benchmark for the Alpha Cronbach test conducted by the researchers.

Table 3. Interpretation of Alpha Cronbach's reliability coefficient

\begin{tabular}{cc}
\hline Reliability coefficient & Level of Reliability \\
\hline 0.90 or more & Very Good \\
$0.80-0.89$ & Good \\
$0.60-0.79$ & Average \\
$0.40-0.59$ & Doubted \\
$0.00-0.39$ & Rejected \\
\hline
\end{tabular}

Table 4. Alpha Cronbach's Reliability Index for Each Part of the Study Instrument

\begin{tabular}{ccc}
\hline Section & Number of Items & Alpha Cronbach \\
\hline Existing Knowledge & 5 & 0.600 \\
Interest & 5 & 0.800 \\
Attitude & 5 & 0.800 \\
Lecturer & 5 & 0.897 \\
Peers & 5 & 0.805 \\
Environment & 5 & 0.935 \\
\hline
\end{tabular}




\section{Data Collection}

The research instrument used to collect data is by using a set of questionnaire questions. The questionnaire was then distributed to 179 respondents. The distribution of the questionnaire was conducted directly to the students by providing a brief description of the purpose of the study and how to answer the questionnaire to the respondents. According to Hopes, C., Kramer, J., Williams, K. (2006), meeting with respondents was more effective than asking them to come to the researcher. Respondents' responses were the primary data for this study.

\section{Data Analysis}

Statistical tests were performed to analyze the results of this study using descriptive analysis to find the frequency, mean and standard deviation values. Data were analyzed using SPSS Software version 23. Table 5 shows the mean level of acceptance by Mohamed Najib (1999) used as a guide in this study.

Table 5. Level of Score Mean

\begin{tabular}{cc}
\hline Mean Score Range & Level of Mean Score Value \\
\hline $1.00-1.49$ & Very Low \\
$1.50-2.49$ & Low \\
$2.50-3.49$ & Average \\
$3.50-4.49$ & High \\
$4.50-5.00$ & Very High \\
\hline
\end{tabular}

T-tests were also conducted to determine if there were any differences in performance levels between male and female students taking Engineering Science Course. In addition, Pearson Correlation Analysis was also used to answer the questionnaire to find out whether there is a relationship between item of lecturer, peers, environment with student interest using relationship strength scale based on correlation coefficient values by Cohen, Manion and Marrison (2011) as shown in Table 6.

Table 6. Relationship Strength According to Correlation Coefficient Values

\begin{tabular}{cc}
\hline Correlation Coefficient Size (r) & Correlation Strength \\
\hline \pm .81 to 1.00 & Very Strong \\
\pm .51 to .80 & Strong \\
\pm .31 to .50 & Average \\
\pm .21 to .30 & Weak \\
\pm .01 to .20 & Very Weak \\
\hline
\end{tabular}

\section{Results and Discussions}

Table 4.1.1 shows the background of the survey respondents by gender. The results showed that out of 179 respondents, $68.70 \%$ of which 123 were male, while $31.30 \%$ of 56 were female. This result shows that for December 2019 intake, the number of females is more than male.

Table 7. Respondents' Background by Gender

\begin{tabular}{cccc}
\hline No & Gender & Numbers & Percentages (\%) \\
\hline 1 & Male & 123 & 68.70 \\
2 & Female & 56 & 31.30 \\
& Total & 179 & 100 \\
\hline
\end{tabular}

Table 4.1.2 shows the background of respondents by age. 120 people, $67.00 \%$ were 18 to 19 years old, while 51 people $28.50 \%$ were 20 to 21 years old, 7 people $3.90 \%$ were 22 to 24 years old and 1 person, $0.60 \%$ were 25 years old. The highest percentage of respondents was the sample aged 18 to 19 compared with the respondents over the age of 25 which was 1 person. 
Table 8. Respondents' Background by Age

\begin{tabular}{cccc}
\hline No & Age & Numbers & Percentages (\%) \\
\hline 1 & $18-19$ years & 120 & 67.00 \\
2 & $20-21$ years & 51 & 28.50 \\
3 & $22-24$ years & 7 & 3.90 \\
4 & $>25$ years & 1 & 0.60 \\
& Total & 179 & 100 \\
\hline
\end{tabular}

Table 4.1.3 shows the background of respondents by department and program. The results showed that 29 people (16.20\%) were from JKA, JKM was represented by 45 respondents $(23.50 \%)$. Meanwhile, JKE was $32(17.80 \%)$ and JMSK was $73(40.80 \%)$. The percentage of admissions in the December 2019 session indicated that there were more diploma students than pre-diploma students.

Table 9. Respondents' Background by Department and Program

\begin{tabular}{ccccc}
\hline No & Department & Program & Numbers & Percentages (\%) \\
\hline 1 & JKA & DKA & 29 & 16.20 \\
2 & JKM & DKM & 21 & 11.00 \\
3 & & DAD & 13 & 7.30 \\
4 & & DEM & 6 & 3.40 \\
5 & & DTP & 5 & 2.80 \\
6 & JKE & DEE & 16 & 8.90 \\
7 & & DTK & 14 & 7.80 \\
8 & & DEP & 2 & 4.10 \\
9 & JMSK & IPS & 73 & 40.8 \\
& & Total & 179 & 100 \\
\hline
\end{tabular}

Table 9 shows the background of respondents according to SPM's current stream/discipline. It is found that $24 \%$ of respondents follow science discipline, $6.70 \%$ commerce discipline, $13.40 \%$ respondents attended accounting discipline, $7.30 \%$ follow business discipline. Whereas the literary - literature discipline is $26.30 \%$, the visual arts discipline is $8.40 \%$, the economic discipline is $7.30 \%$. Computer science discipline is $2.20 \%$. Electrical and geographic discipline are $1.70 \%$ and respondents taking mechanical and Islamic studies is $0.60 \%$. In conclusion, $60.3 \%$ of the respondents did not take physics subject compared to $39.7 \%$ attended physics subject when they were in school.

Table 10. Respondents' Background by SPM Discipline

\begin{tabular}{cccc}
\hline No & Background & Numbers & Percentages (\%) \\
\hline 1 & Science & 43 & 24.00 \\
2 & Commerce & 12 & 6.70 \\
3 & Accounting & 24 & 13.40 \\
4 & Business & 13 & 7.30 \\
5 & Literature & 47 & 26.30 \\
6 & Visual arts education & 15 & 8.40 \\
7 & Economy & 13 & 7.30 \\
8 & Electrical & 3 & 1.70 \\
9 & Mechanical & 1 & 0.60 \\
10 & Computer Science & 4 & 2.20 \\
11 & Islamic studies & 1 & 0.60 \\
12 & Geography & 3 & 1.70 \\
\hline & Total & 179 & 100 \\
\hline
\end{tabular}

Study Question 1: What factors influence students' performance in Engineering Science Courses?

Table 10 shows the existing knowledge factors for Engineering Science Courses. The results show that for items with a mathematical basis, the mean value obtained is 3.92 with a standard deviation of 0.73 . For items with a physical basis, the mean value is 2.61 with a standard deviation of 1.23 . For items with a scientific basis, the mean value is 4.00 with a standard deviation of 0.64 . For proficient items in unit conversion basis, mean value is 3.50 with standard deviation 0.76 and proficient in calculator, mean value is 3.92 with standard 
deviation 0.73 Based on scoring level table, mean value for math basis, science base, proficient in unit conversion and proficient in calculators at a high level, while having a basic physics at a moderate level. This value indicates that the mean score level is high with an overall value of 3.59.

Table 11. Existing Knowledge Factors in Engineering Science Course

\begin{tabular}{ccccc}
\hline No & Item & Mean & Mean Score Level & Standard deviation \\
\hline B1 & Has basic maths & 3.92 & High & 0.73 \\
B2 & Has basic physics & 2.61 & Average & 1.23 \\
B3 & Has basic science & 4.00 & High & 0.64 \\
B4 & Proficient in unit conversion & 3.50 & High & 0.76 \\
B5 & Proficient in using calculator & 3.92 & High & 0.73 \\
& Average Mean & 3.59 & High & 0.82 \\
\hline
\end{tabular}

Table 11 shows the factors of interest in Engineering Science Courses. The results showed that items like to attend engineering science class, mean value is 3.99 with standard deviation of 0.78 . It is fun to study Engineering Science Course, mean value is 4.00 with standard deviation 0.75 . For daily exercise items, the mean value is 3.63 with a standard deviation of 0.76 . Items for pre-preparation preparations, mean value is 3.75 with standard deviation 0.76 and item always completed assigned tasks, mean value 4.15 with standard deviation 0.64 . Based on this table, it clearly shows that the score for all items is at a high level with an overall mean score of 3.90 and students have an interest in improving their Engineering Science Course performance.

Table 12. Interest Factors in Engineering Science Course

\begin{tabular}{ccccc}
\hline No & Item & Mean & Mean Score Level & Standard deviation \\
\hline C1 & $\begin{array}{c}\text { Enjoy attending Engineering } \\
\text { Science classes }\end{array}$ & 3.99 & High & 0.78 \\
C2 & $\begin{array}{c}\text { Enjoy studying Engineering } \\
\text { Science Courses }\end{array}$ & 4.00 & High & 0.75 \\
C3 & $\begin{array}{c}\text { Doing exercises every day } \\
\text { Make early preparations before } \\
\text { class }\end{array}$ & 3.63 & High & 0.76 \\
C5 & $\begin{array}{c}\text { Always complete assigned } \\
\text { tasks }\end{array}$ & 4.75 & High & 0.76 \\
& Average Mean & 3.90 & High & 0.64 \\
& & High & 0.74 \\
\hline
\end{tabular}

Table 12 shows the factors of attitude towards Engineering Science Course. The results found the mean scores for items D1, D2, D3, D4, D5 to be high with an overall mean score of 3.98 with a standard deviation of 0.65 . The findings show that students have a very positive attitude towards Engineering Science Course.

Table 13. Attitude Factors in Engineering Science Course

\begin{tabular}{ccccc}
\hline No & \multicolumn{1}{c}{ Item } & Mean & Mean Score Level & Standard deviation \\
\hline D1 & $\begin{array}{c}\text { Give full focus during the } \\
\text { Engineering Science Course } \\
\text { learning sessions } \\
\text { Understand Engineering } \\
\text { Science Course easily } \\
\text { Likes to interact with the } \\
\text { lecturers during the } \\
\text { Engineering Science Course } \\
\text { learning session }\end{array}$ & 4.20 & High & 0.59 \\
D3 & 3.61 & High & 0.71 \\
D4 & $\begin{array}{c}\text { Write the formula during the } \\
\text { Engineering Science Course } \\
\text { learning session }\end{array}$ & 4.01 & High & 0.63 \\
D5 & $\begin{array}{c}\text { Always be prepared to attend } \\
\text { Engineering Science Course } \\
\text { classes }\end{array}$ & 4.08 & High & 0.60 \\
& $\begin{array}{c}\text { Average Mean } \\
\text { Aigh }\end{array}$ & 3.98 & High & 0.73 \\
\hline
\end{tabular}


Table 13 shows the factor of lecturers for the Engineering Science Course, the mean score for item E1 is 4.15 with a standard deviation of 0.70 . Item E2, mean value 4.13 with standard deviation 0.69 . item E3, the mean value was 4.26 with a standard deviation of 0.64 . For item E4, mean value 4.20 with standard deviation 0.67 and item E5, mean value 4.29 with standard deviation 0.66 . The results show that the overall mean value of 4.21 is high. This shows that the lecturers are always helping the students and are focusing on improving student performance in the Engineering Science Course.

Table 14. Lecture Factors in Engineering Science Course

\begin{tabular}{ccccc}
\hline No & Item & Mean & Mean Score Level & Standard deviation \\
\hline E1 & $\begin{array}{c}\text { Always provide guidance in } \\
\text { the classroom }\end{array}$ & 4.15 & High & 0.70 \\
E2 & $\begin{array}{c}\text { Provides clear and } \\
\text { understandable explanations }\end{array}$ & 4.13 & High & 0.69 \\
E3 & $\begin{array}{c}\text { Use language that is easy to } \\
\text { understand }\end{array}$ & 4.26 & High & 0.64 \\
E4 & $\begin{array}{c}\text { Always emphasize training } \\
\text { questions }\end{array}$ & 4.20 & High & 0.67 \\
E5 & $\begin{array}{c}\text { Give positive encouragement } \\
\text { in the classroom }\end{array}$ & 4.29 & High & 0.66 \\
& $\quad$ Average Mean & 4.21 & High & 0.67 \\
\hline
\end{tabular}

Table 14 shows the peer factors of Engineering Science Course. As can be seen from the table, the mean value for item F1 is 4.01 with a standard deviation of 0.69 . The mean value for item F2 is 4.22 with a standard deviation of 0.547 . For item F3, the mean value is 4.09 with a standard deviation of 0.66 . Item F4 has a mean of 4.14 with a standard deviation of 0.59 . item F5 gives a mean of 4.21 with a standard deviation of 0.62 . Based on the score acceptance table, the mean value for all items is high. The overall mean value of this section is 4.13 , which is at the high mean score level. The findings show that peers are extremely helpful and have a positive impact on teamwork in order to achieve the best in Engineering Science Course.

Table 15. Peer Factors for Engineering Science Course

\begin{tabular}{|c|c|c|c|c|}
\hline No & Item & Mean & Mean Score Level & Standard deviation \\
\hline F1 & $\begin{array}{l}\text { Learn a lot about Engineering } \\
\text { Science Course through friends }\end{array}$ & 4.01 & High & 0.69 \\
\hline $\mathrm{F} 2$ & $\begin{array}{l}\text { Have friends who are always } \\
\text { helpful in completing } \\
\text { assignments given by lecturers }\end{array}$ & 4.22 & High & 0.57 \\
\hline F3 & $\begin{array}{l}\text { Reviewing Engineering Science } \\
\text { Course with friends }\end{array}$ & 4.09 & High & 0.66 \\
\hline $\mathrm{F} 4$ & $\begin{array}{c}\text { Sharing problems in } \\
\text { Engineering Science Course } \\
\text { with friends }\end{array}$ & 4.14 & High & 0.59 \\
\hline F5 & $\begin{array}{l}\text { Always cooperate with } \\
\text { colleagues while conducting } \\
\text { Engineering Science } \\
\text { experiments }\end{array}$ & 4.21 & High & 0.62 \\
\hline & Average Mean & 4.13 & High & 0.63 \\
\hline
\end{tabular}

Table 15 shows the environmental factors of the Engineering Science Course. As can be seen, item G1 has a mean value of 4.23 with a standard deviation of 0.70 . item $\mathrm{G} 2$, mean value 4.27 with standard deviation 0.61 . For items G3 gives a mean of 4.33 with a standard deviation of 0.55 . Item G4 shows mean value of 4.34 with mean score of 0.59 and item G5, mean value is 4.36 and standard deviation is 0.57 . The results show that the overall mean score value of 4.31 is high. This indicates that conducive and safe environmental factors also play an important role in helping to improve student performance. 
Table 16. Environmental Factors of Engineering Science Course

\begin{tabular}{|c|c|c|c|c|}
\hline No & Item & Mean & Mean Score Level & Standard deviation \\
\hline G1 & $\begin{array}{c}\text { The conducive science / } \\
\text { lecture room }\end{array}$ & 4.23 & High & 0.70 \\
\hline G2 & $\begin{array}{l}\text { The lighting of the lecture hall } \\
\text { / science lab is perfect }\end{array}$ & 4.27 & High & 0.61 \\
\hline G3 & $\begin{array}{l}\text { Clean, well-organized science } \\
\text { lecture / laboratory room }\end{array}$ & 4.33 & High & 0.55 \\
\hline G4 & $\begin{array}{l}\text { Engineering Science equipment } \\
\text { and supplies are sufficient }\end{array}$ & 4.34 & High & 0.59 \\
\hline \multirow[t]{2}{*}{ G5 } & $\begin{array}{c}\text { Safe classroom / science lab } \\
\text { environment }\end{array}$ & 4.36 & High & 0.57 \\
\hline & Average Mean & 4.31 & High & 0.60 \\
\hline
\end{tabular}

\section{Study Question 2: Is there a difference in attitudes between students' genders?}

Table 16 shows the differences in attitudes between men and women. Findings, values $(t=-2.080), p<0.05$ (0.039) for attitude. The items with this attitude value $\mathrm{p}<0.05$. Therefore, it can be concluded that there are significant differences in attitude items. Men and women have different views. Then Ho-1 was rejected.

Table 17. T-test Differences in attitudes between students' genders?

\begin{tabular}{ccccccc}
\hline Item & Gender & $\mathbf{N}$ & Mean & $\begin{array}{c}\text { Standard } \\
\text { Deviation }\end{array}$ & $\mathbf{t}$ & Sig. (2-tailed) \\
\hline Attitude & Lelaki & 123 & 4.03 & 0.509 & 2.080 & 0.039 \\
& Perempuan & 56 & 3.56 & 0.453 & & \\
\hline
\end{tabular}

Study Question 3: Is there a relationship between faculty, peers and students' interest in the environment?

The results in table 17 show that there was a significant relationship between the three items with significant value, $\mathrm{p}<.05$, so H1-2 was accepted. There was a simple and positive correlation between lecturers and interests with $\mathrm{p}=.000$ and coefficient values, $\mathrm{r}=0.480$.

On the other hand, there was a strong and positive correlation between peers and student's interest with significant, $\mathrm{p}=.000$ and coefficient, $\mathrm{r}=0.524$.

Meanwhile, the relationship of the last two items: student environment and interest with significant, $p=$ .000 and coefficient value, $r=0.564$ with strong and positive correlation. This indicates that the conducive environment is important in increasing students' focus and interest in T\&L.

Table 18. Correlations between the relationships between lecturers, peers and students' interest environment

\begin{tabular}{ccccc}
\hline & Mean & Standard Deviation & $\begin{array}{c}\text { Pearson Correlation } \\
\text { (r) }\end{array}$ & $\begin{array}{c}\text { Sig. (2-tailed) } \\
\text { (p) }\end{array}$ \\
\hline Lecturer & 4.21 & 0.58 & 0.480 & 0.000 \\
Peers & 4.13 & 0.49 & 0.524 & 0.000 \\
Environment & 4.31 & 0.53 & 0.564 & 0.000 \\
\hline ** significant correlation at the level 0.01 (2-tailed) & &
\end{tabular}

\section{Results and Discussions}

Based on the analysis conducted, 179 respondents answered the questionnaire distributed and respondents consisted of students taking Engineering Science Courses in the June 2019 session. Out of 179 respondents of $68.70 \%$ were male students and the remaining $31.30 \%$ were female. $67 \%$ of the students attending PSMZA in the June 2019 session were 18-19 years old, $28.5 \%$ were $20-21$ years old. Meanwhile, 3.9\% were 22-24 years old and $0.6 \%$ were 25 years old. The proportion of respondents by department, JKA (16.20\%), JKM (23.50\%), JKE (17.80\%) and JMSK (40.80\%). While SPM's current disciplines of respondents found that the highest percentage of respondents studying in PSMZA were literature (26.30\%), science (24\%), accounting (13.40\%), visual arts education $(8.40 \%)$, business and economic (7.3\%), computer science $(2.20 \%)$, electrical and geographical (1.70\%) and mechanical and Islamic studies $(0.60 \%)$ disciplines. 
In this study, five factors that influence students' performance in the Engineering Science Course at PSMZA were studied. These factors are, existing knowledge, interests, attitudes, lecturers, peers and the environment. Based on the mean score analysis for all of these factors, the environmental factor gave the highest mean value compared to other factors with a value of 4.31. Meanwhile, the existing knowledge factor gives the lowest mean value of 3.59. This answers the first research question, which environment is the most influential factor in student performance at PSMZA in Engineering Science Courses. This is in line with the study by Frenzel et al., (2007) that learning is optimal when the body and soul are in tune with the conducive and safe classroom environment and otherwise the learning will be ineffective. Studies by Madar, A. R., Kamaruddin, N. A., \& Puteh, S. (2005) in three polytechnics across Malaysia also found that environmental factors are among the highest contributors to student achievement. Ahmad, C. N. C., Osman, K., \& Halim, L. (2010) also mentioned that good environmental factors enable integration of learning theory and practice, as well as give students the opportunity to generate ideas.

To answer the second study question, a T-test was performed. The results of the analysis show that there is a gender difference in Engineering Science Course with $p=0.039$. This is supported by the study of Ismail, N., \& Mahamod, Z. (2016) and Kadir M. N. B. B. A. (2016) who found that gender differences contribute to students' differences in learning.

For the third research question, the Pearson Correlation analysis conducted found that there is a strong and positive relationship between peers and the environment of student interest. Lecturers, on the other hand, have a simple and positive relationship with students' interests. The results of this study are in line with the findings of Mohd Jelas et al. (2014) found that peer learning support is a factor that contributes directly to student achievement. The findings of this study are further reinforced by the findings of Lam et al. (2012) who showed that the support of the learning of teachers, peers and parents directly affected student engagement in achievement.

Based on the analysis of this study, the researchers found that all of the factors listed contributed to the improvement in student performance. The highest mean value is the environmental factor of 4.31 . The existing knowledge factor gave the lowest mean value of 3.59. However, this value is still within the range of the high mean value score range. However, the existing knowledge factors provide lower mean values probably due to the respondents' background of $76 \%$ not from science stream. They come from various fields. Their willingness to study hard in the Engineering Science Course deserves credit. The highest value environmental factors still have room for improvement. This is because, the conducive environment requires constant maintenance. Provision of organizational management is essential to ensure that the laboratory and classroom environment are kept up to date with a conducive environment, adequate facilities, good lighting and consistent use of established safety procedures.

Some limitations of this study can be seen in this study. First, this study focuses on first semester students taking Engineering Science Courses. In the future, studies may be conducted on respondents from other semester students, who take other courses in polytechnics across Malaysia. This study is important to enable us to find the right learning space for students so that they do not fail in any given subject or course. Different approaches may be made to different students. This is also a process that needs to be continued. In addition, we can identify other factors that may lead to an increase or decrease in a student's performance.

Second, the analysis methods used for this research are descriptive, T-test and Pearson Correlation. Future studies may allow researchers to use a more comprehensive and detailed analysis. Among others, relate student achievement to a subject or course, with factors that may contribute to that achievement.

\section{Conclusions}

Polytechnic is a large organization with ample facilities that has produced many graduates since its inception. Over the years we have celebrated many young people coming out of the polytechnic with high levels of job success and marketability. However, for many polytechnic's educators, they do not forget the few who failed to graduate. This percentage is small, but it has great potential if we can identify and address the causes of their failure early. Didn't they also initially enroll in polytechnics with big dreams? Therefore, such studies need to be carried out on an ongoing basis to enable us to constantly find space to improve our education system. This is important in ensuring that none of our potential students are wasted. 


\section{References}

Abdullah, A. H., Hamzah, M. H., Hussin, R. H. S. R., Kohar, U. H. A., Rahman, S. N. S. A., \& Junaidi, J. (2017, December). Teachers' readiness in implementing science, technology, engineering and mathematics (STEM) education from the cognitive, affective and behavioural aspects. In 2017 IEEE 6th International Conference on Teaching, Assessment, and Learning for Engineering (TALE) (pp. 6-12). IEEE.

Ahmad, C. N. C., Osman, K., \& Halim, L. (2010). Hubungan ramalan persekitaran pembelajaran makmal sains dengan tahap kepuasan pelajar. Jurnal Pendidikan Malaysia, 35(2), 19-30.

Ayob, A. (2012). Cara Meningkatkan Minat Pelajar terhadap Sains dan Matematik.Universiti Pendidikan Sultan Idris.

Bunimin, J. (2016). Model konsep pembangunan profesionalisme tenaga pengajar kolej vokasional Malaysia (Doctoral dissertation, Universiti Tun Hussein Onn Malaysia).

Cohen, L., Manion, L., \& Marrison, K. (2011). Research methods in education (7th ed.). New York, USA: Routledge Taylor \& Francis Group.

Frenzel, A.C., Pekrun, R., \& Goetz, T., (2007): Perceived Learning Environment and Students' Emotional Experiences: A Multilevel Analysis of Mathematics Classrooms. (c) Elsevier Ltd. All rights reserved. Learning and Instruction 17 (2007) 478e493 www.elsevier.com/locate/learninstruc

Gay, L. R. dan Airasian, P. (2003). Educational research: Competencies for analysis and applications (7th ed.). Ohio: Merrill Prentice Hall.

Hopes, C., Kramer, J., Williams, K., (2006), Public Involvement Practices and Perspectives of Florida's Metropolitan Planning Organizations, Transportation Research Record No. 1981, 100- 108, Washington, D.C.

Hussin, S. (2014). Cabaran menyeluruh dalam pelaksanaan transformasi pendidikan untuk masa depan malaysia. In Seminar Transformasi Pendidikan Nasional.

Ismail, N., \& Mahamod, Z. (2016). Sikap dan kesediaan pelajar sekolah menengah terhadap kemahiran berfikir aras tinggi dalam pembelajaran komsas bahasa melayu (Attitude and Readiness Secondary School Students on Higher Order Thinking Skill in Malay Language Literature Component). Jurnal Pendidikan Bahasa Melayu, 6(2), 59-67

Kadir, M. N. B. B. A. (2016). Sikap Pelajar Terhadap Pembelajaran Fizik dan Hubungannya Dengan Pencapaian Dalam Kalangan Pelajar Sains (Students Attitude Towards Physics and Relationship with Achievement among Science Students) Mohd Noor Badlilshah Bin Abdul Kadir, Mohd Mustamam Abdul Karim \& Nurulhuda Abd. Rahman. Jurnal Personalia Pelajar, 19, 31-51.

Krejcie R.V., \& Morgan D.W. (1970). Determining sample size for research activities. Educational and Psychological Measurement 30, 607-610.

Lam, S. F., Jimerson, S., Kikas, E. Cefai, C., Verga, F. H., Nelson, B., Hatzichristou, C., Polychroni, F., Basnett, J., Duck, R., Farrell, P., Liu, Y., Negovan, V., Shin, H., Stanculescu, E., Wong, B. P. H., Yang, H. \& Zollneritsch, J. (2012). Do girls and boys perceive themselves as equally engaged in school? The result of an international study from 12 countries. Journal of School Psychology, 50(1), 77-94.

Madar, A. R., Kamaruddin, N. A., \& Puteh, S. (2005). Faktor-faktor yang mempengaruhi pencapaian pelajar dalam menguasai mata pelajaran kejuruteraan di politeknik politeknik kementerian pengajian tinggi Malaysia.

Mior Jamaluddin, M. K. A. (2011). Sistem pendidikan di Malaysia: Dasar, cabaran, dan pelaksanaan ke arah perpaduan nasional. Sosiohumanika, 4(1).

Mohd Jelas, Z., Salleh, A., Azman, N., Jani, R., Hamzah, R., Mahmud, I., Ab Hamid, Z., Hamzah., H \& Zulnaidi, H. (2014). Gender differences in learning support and academic achievement: The mediating role of student engagement. Malaysian Journal of Learning and Instruction,11(1), 237-262.

Mohd Majid, K. (2000). Kaedah penyelidikan pendidikan. Dewan Bahasa dan Pustaka. Kuala Lumpur.

Mohamad Najib Abdul Ghafar (1999). Penyelidikan Pendidikan. Skudai: Penerbitan Universiti Teknologi Malaysia

Pelan Strategik Pengajian Tinggi Negara - PSPTN, Fasa 2, (2011-2015).

Portal Rasmi Bahagian Ambilan dan Pembangunan Pelajar Jabatan Pendidikan Politeknik dan Kolej Komuniti (2020). Didapati daripada: http://ambilan.mypolycc.edu.my/portalbpp2/index.asp?pg=politeknik

Penn state university (2013). What is Engineering Science http://www.es,.psu.edu/about/whatisesci/ [May 6]

Sekaran,U., \& Wiley, J. (2006). Data collection methods. Research methods for business: A skill building approach, 218-262. 